\title{
Form and function in juvenile ascidians. I. Implications of early juvenile morphologies for performance
}

\author{
Kristin M. Sherrard ${ }^{1,3, *}$, Michael LaBarbera ${ }^{1,2}$ \\ ${ }^{1}$ Committee on Evolutionary Biology and ${ }^{2}$ Department of Organismal Biology and Anatomy, University of Chicago, Chicago, \\ Illinois 60637, USA \\ ${ }^{3}$ Present address: Friday Harbor Laboratories, 620 University Road, Friday Harbor, Washington 98250, USA
}

\begin{abstract}
Newly settled marine invertebrates are typically less than $1 \mathrm{~mm}$ tall and face physical and biotic factors distinct from those facing adults, including a fluid environment dominated by high viscosity and deep boundary layers, and a size-specific suite of predators and competitors. If juveniles have distinct morphologies from adults, or morphologies that function differently at small scales, these differences could have important implications for juvenile performance. We compared the ontogenetic scaling of morphological parameters related to suspension feeding in 6 species of ascidians covering a wide taxonomic range. Many aspects of early juvenile morphology differed from those of conspecific adults, though not invariably in ways likely to improve feeding performance at small size. Some juvenile morphologies that are detrimental to efficient suspension feeding may serve other functions, whereas others are the result of commencing suspension feeding before the completion of metamorphosis. Thus, not all ascidian species appear specialized for higher rates of suspension feeding and early growth.
\end{abstract}

KEY WORDS: Early juvenile · Ascidian · Ontogenetic scaling · Suspension feeding morphology

Resale or republication not permitted without written consent of the publisher

\section{INTRODUCTION}

Early juveniles of marine invertebrates face sizespecific challenges to growth and survival that are likely to be distinct from those facing adults. They face a different suite of predators (Osman \& Whitlach 1995) and a fluid dynamic environment in which viscous forces dominate (Vogel 1994), making pumping more costly. As they grow, the mechanics of flow generation change as viscous forces become progressively less dominant and inertial forces more so. Thus, gradual or sudden changes in function may occur even in the absence of morphological changes (Koehl 1996).

More generally, early juvenile stages constitute a critical stage in life histories, influencing patterns of survival, abundance and species ranges (Goodbody 1963, Connell 1985, Stoner 1990, Keesing \& Halford 1992, Osman et al. 1992, Osman \& Whitlatch 1995, 1996, Hunt \& Scheibling 1997). The disproportionately high mortality rates in the first days and weeks after settlement (Gosselin \& Qian 1997) suggest selection acts strongly on juveniles (Moran 1999). However, there have been few studies on the morphological and functional correlates to early juvenile performance (Moran 1999, Moran \& Emlet 2001).

Ascidians are an excellent group in which to examine putative juvenile adaptations. Much of their morphology can be linked to functions related to active suspension feeding, which has been studied extensively in adult ascidians and bivalves (e.g. FialaMedioni 1978, Flood \& Fiala-Medioni 1979, Randløv \& Riisgård 1979, Jørgensen et al. 1984, Riisgård 1988, Petersen \& Riisgård 1992, Riisgård \& Larsen 1995, Kowalke 1999, Petersen \& Svane 2002). The physical mechanisms of flow generation during active suspension feeding are well understood, and the effects of morphology and size on feeding performance are readily quantifiable (Rubinstein \& Koehl 1977, Jør- 
gensen et al. 1984, LaBarbera 1984, Riisgård 1988). Finally, because ascidians are entirely sessile suspension feeders that have no energy budget for movement or foraging, and whose juveniles consume the same resource and live in the same habitat as adults, comparisons of feeding performance throughout ontogeny are simplified.

During ascidian feeding, water is drawn through the incurrent siphon and into the pharyngeal basket. The water passes out through perforations in the basket (stigmata), which are lined with cilia that drive the flow, and exits through the excurrent siphon (see Fig. 1). Food particles are captured with high retention efficiency (Randløv \& Riisgård 1979) on a mucous net inside the basket and, together with the net, are passed into the stomach. We will focus here on the effects of siphon and basket morphology on the resistance to flow, pump power and the region of water sampled.

Early juvenile suspension feeders face a number of mechanical constraints to efficient suspension feeding. Actively pumping suspension feeders that process fluid internally, such as bivalves, brachiopods, a few gastropods and tunicates, would be expected to experience high resistance to pumping at small size (Grunbaum et al. 1998). Furthermore, benthic food depletion by suspension feeders is a common phenomenon (Buss \& Jackson 1981, Riisgård et al. 1996) and effects would be magnified for small organisms living deep within velocity boundary layers (Nowell \& Jumars 1984, Arsenault et al. 1997).

Ascidians include both solitary forms, which experience ontogenetic increases of up to 7 orders of magnitude in volume, and colonial forms, which grow by clonal addition and whose units grow little or not at all during ontogeny. Furthermore, colonial ascidians settle at sizes 5 to 15 times the volume of solitary ascidians, providing a test of how initial size impacts feeding performance and other aspects of performance.

It is difficult to prove that putative adaptations have indeed been subject to selection (Rose \& Lauder 1996). Here, we will address 3 questions which could provide evidence for juvenile adaptation in ascidians. First, do distinct juvenile morphologies exist? Second, if so, what are their implications for suspension feeding proficiency and other aspects of growth and survival? Third, are juveniles of colonial species, whose feeding units remain small throughout the colony lifetime, better suited for efficient feeding at small size than are juveniles of solitary species which are only small for a brief portion of ontogeny? To address these questions, we documented the ontogenetic trajectories of juvenile morphologies in 6 ascidian species, including 2 solitary phlebobranchs Corella inflata and Ciona savignyi, 2 solitary stolidobranchs Boltenia villosa and Styela gibbsi, 1 colonial stolidobranch Botrylloides violaceus and 1 colonial aplousobranch Distaplia occidentalis. Because coloniality probably evolved independently in aplousobranchs and stolidobranchs (Berrill 1950, Kott 1969, Wada et al. 1992, Swalla et al. 2000, Stach \& Turbeville 2002), this provides 2 independent instances of coloniality to compare with the solitary condition.

\section{MATERIALS AND METHODS}

Animal culture. We collected reproductive Corella inflata, Boltenia villosa, Styela gibbsii, Botrylloides violaceus and Distaplia occidentalis from floating docks in the vicinity of Friday Harbor Laboratories, and Ciona savignyi from Edmonds Marina, Puget Sound (all locations in Washington state, USA). We obtained larval ascidians either from brooding adults (in the colonial species Distaplia occidentalis and Botrylloides violaceus, and the solitary species Corella inflata), or by dissecting out gonads and fertilizing ripe eggs (in the solitary species Boltenia villosa, Styela gibbsii and Ciona savignyi). Species will hereafter be referred to by their genus names alone.

Embryos and larvae were kept in $1 \mathrm{l}$ beakers until they settled on labeled acrylic plastic blocks approximately $1 \mathrm{~cm}^{3}$ in volume. After settlement, juveniles were kept in a flow-through seawater table. Four hundred $\mathrm{ml}$ of cultured Rhodamonas and/or Isochrysis in exponential growth phase were added daily as a supplementary food source.

Morphological measurements. We photographed animals using an Olympus BH2 trinocular compound microscope or a Wild Leica MZ6 trinocular dissecting microscope, a Sony 3 CCD video camera (SSC-S20) attached by S-video line to a Sony TRV-900 digital video camcorder (which served simply as a recording deck) and a Nikon Coolpix 990 digital camera. We photographed individual oozooids (the initial zooid derived from the larva) of colonial species daily from 0 to $12 \mathrm{~d}$ after settlement. We photographed Corella and Ciona, which do not begin feeding until at least $5 \mathrm{~d}$ after settlement, from 5 to $75 \mathrm{~d}$, as well as subadults and adults. We photographed Boltenia and Styela at $10 \mathrm{~d}$ post-settlement, when feeding commences, and at $17,31,45$ and $66 \mathrm{~d}$, as well as subadults and adults collected in the wild.

We used NIH Image 1.62 to measure the height of the incurrent siphon midpoint, incurrent and excurrent siphon diameters (siphons were circular in crosssection) at the outer edge of uncontracted siphons in normally feeding animals. We measured top and lateral body areas by carefully tracing the entire outline of the animal including the tunic and siphons. Photographs of a stage micrometer were used as a reference 
for scale; linear and area measurements were reproducible within $5 \%$. Because early juveniles of Corella and Ciona have 2 excurrent siphons, we calculated their excurrent siphon 'radii' in 2 ways: as either the radius of a single siphon or as the square root of total siphon cross-sectional area. The latter measure underestimates the resistance to flow through 2 siphons, which would be $2 \sqrt{2}$ (about $180 \%$ ) higher, although pressure drop through each siphon would be only $140 \%$ higher, because half the volumetric flow passes through each siphon.

We measured incurrent siphon length as the perpendicular distance from siphon tip to the pharyngeal basket. Excurrent siphon lengths corresponded to incurrent lengths, so are not reported here. We measured stigmatal perimeters on half the body from side view. These measures were corrected for body curvature in Botrylloides oozooids, which have long, circumferentially oriented stigmata. In large subadults and adults, we measured stigmata over a smaller area (5 to $20 \%$ of total basket area) and multiplied by the inverse of the fraction of total basket surface area. Stigmata are evenly placed, and this method was accurate and repeatable within a specimen.

Dry masses. As a check on area measurements and to ensure inter-species comparability, we measured dry mass and ash-free dry mass for an ontogenetic range in Ciona, Corella, Botrylloides and Distaplia. We photographed individuals and then fixed them in $5 \%$ buffered formalin in seawater for at least $8 \mathrm{wk}$. We soaked specimens in distilled water for at least $48 \mathrm{~h}$, dried them in aluminum boats at $60^{\circ} \mathrm{C}$ to constant mass and weighed the specimens on a Perkin-Elmer microbalance (precision within $5 \mu \mathrm{g}$ over multiple days) that was shielded from air currents by a glass box. We ashed the samples at $500^{\circ} \mathrm{C}$ for $3 \mathrm{~h}$, cooled them in a drying oven and reweighed them to determine ashfree dry mass.

We measured the entire size range of colonial oozooids and some young colonies as well. The measured range of solitary species was from $0.6 \mathrm{~mm}^{2}$ (projected area) in juveniles (approximately $3 \mathrm{wk}$ old Corella and Ciona) to $800 \mathrm{~mm}^{2}$ (Corella) and $3000 \mathrm{~mm}^{2}$ (Ciona) in large adults. It was not possible to determine the mass to area scaling of younger juveniles of Corella and Ciona due to instrument limitations; individuals weigh an estimated $0.01 \mu \mathrm{g}$ so at least 1000 would be needed to attain an error $\leq 10 \%$, for a balance accurate to $1 \mu \mathrm{g}$. The smallest individuals analyzed $\left(<10 \mathrm{~mm}^{2}\right.$ projected area) were pooled in sets of 3 to 12, weighing a total of 16 to $269 \mu \mathrm{g}$.

Scaling and statistics. Isometric predictions were based on geometric isometry, the assumption of shapeinvariance throughout ontogeny. This constitutes a null hypothesis of morphology remaining the same at different ontogenetic stages. Departures from geometric isometry often indicate a tendency to maintain similar function at different sizes. For example, if juvenile ascidians had relatively shorter and wider siphons than adults, they would have more similar resistance to flow. Most morphological variables studied here are linear, so the geometric isometric prediction would be that they scale as a linear dimension to the power of 1 . Stigmatal perimeter is expected to increase not as a linear dimension, but as a length squared, because stigmata grow by multiplying across the branchial basket while retaining the same width. Under these conditions, total stigmatal perimeter increases as a length squared, just as the perimeter of wires in a mesh screen would increase with screen area, as long as mesh size remained constant.

We report reduced major axis (RMA) slopes for base 10 log-transformed values of morphological variables against the square root of lateral body area. The RMA slopes are based on the more appropriate assumption of error in both independent and dependent variables (LaBarbera 1989). Least squares slopes may be obtained by multiplying reported RMA slopes by $r$, the square root of the correlation coefficient (LaBarbera 1989). Correlation coefficients and p-values for regression slopes were calculated using Statview 5.0; only relationships with significant correlation coefficients $(\mathrm{p}<0.05)$ are reported. We calculated the $95 \% \mathrm{BCa}$ (bias-corrected and accelerated) confidence intervals of RMA slopes using a bootstrapping program written by Michael LaBarbera in HiQ 2.2 after Plotnick (1989) and Efron \& Tibshirani (1986). BCa confidence intervals correct for asymmetries in the distribution due to resampling. Slopes of regressions were considered significantly different from isometry at the $p<0.05$ level if $95 \%$ confidence intervals did not overlap with the predicted isometric slope.

Statistical significance of differences of RMA slopes or RMA intercepts between data sets was tested using a permutations test program written by Michael LaBarbera. The program randomly samples the space of all permutations of the combined data sets, testing the null hypothesis that the difference was no greater than might be expected if the 2 samples were drawn from the same population (see Efron \& Tibshirani 1993 for a brief introduction to permutations tests). In a usual run, 2000 randomly generated permutations of the combined data set were used to generate a frequency distribution of expected values of the difference between the slopes or intercepts from each sample. p-values given for species pairs are the probability that the observed difference in the test statistics could have occurred by chance if the 2 samples were actually drawn from the same population. These $p$-values remain valid even when testing groups where 1 of the 
correlation coefficients was not significantly different from 0 .

Suspension feeding at small size. The primary morphological considerations for efficient suspension feeding at small size are available pump power, resistance to flow and height above the substrate. Pump power is proportional to the pump's ciliated area (i.e. stigmatal perimeter), given equivalent density of ciliation (Martinucci et al. 1987) and power output per cilium. Pumping rate is inversely proportional to resistance, which reduces the theoretical maximal volumetric flow rate. Like most suspension feeders, which must process large volumes of water to obtain sufficient food, ascidians operate their pumps at low resistance (Riisgård \& Larsen 1995). However, it is a challenge to do so at small size.

The total resistance to flow through an ascidian is generated by 2 main components. The first is incurrent siphon resistance, as formerly unconfined flow moves into the constriction of the incurrent siphon (hereafter, 'siphonal resistance'). Eq. (1), applicable to siphons of length less than 1 radius at low to moderate Reynolds number, defines this aperture resistance (Vogel 1994):

$$
R_{\mathrm{s}}=\frac{3 \mu}{r^{3}}
$$

where $\mu=$ dynamic viscosity of seawater $(1.072 \times$ $10^{-3} \mathrm{~Pa} \cdot \mathrm{s}$ at $20^{\circ} \mathrm{C}$ ) and $r=$ incurrent siphon radius. Resistance generated in the excurrent siphon is much less than that in the incurrent siphon because flow has already been constricted. The second source of resistance is the mucous net, through whose miniscule apertures (0.2 to $2 \mu \mathrm{m}$ ) (Flood \& Fiala-Medioni 1981) flow must pass. The following equation is modified by dividing the pressure drop equation in Riisgård (1988) by volumetric flow rate to derive mucous net resistance (pressure drop is the product of volumetric flow rate and system resistance, Vogel 1994):

$$
R_{\mathrm{m}}=\frac{8 \mu V}{Q h_{\mathrm{e}} \Lambda_{\mathrm{e}}}=\frac{8 c \mu}{r^{2} h_{\mathrm{e}} \Lambda_{\mathrm{e}}}
$$

where $V=$ velocity at the net, $Q=$ volumetric flow rate, $h_{\mathrm{e}}=$ mesh width and $\Lambda_{\mathrm{e}}=$ radius of mesh fiber; these properties of the mucous net are not likely to change with animal size; $C$ is a scaling term accounting for the different velocities at the siphon entrance and at the mesh surface. The 2 resistance terms in Eqs. (1) \& (2) have approximately equal magnitudes in adult ascidians (Riisgård 1988), but because their ratio is inversely proportional to $r$, siphonal resistance dominates the system for juveniles.

A second parameter expected to strongly affect juvenile feeding performance is height of the incurrent siphon above the substrate. This height determines how far above the substrate water is sampled, which is likely to affect food quality and concentration. Height also affects the position of the subject relative to other animals and macroalgae living in the vicinity, which may compete for food or block flow. Height is determined by siphon length, body height and posture.

In the wild, flow over real substrates such as rocks and docks is more complex and variable than the usual model of flow over flat plates. However, at flows less than $10 \mathrm{~cm} \mathrm{~s}^{-1}$ and within millimeters of a not-too-rough surface, laminar and viscous effects prevail, and simple equations remain applicable. The following equation (after Vogel 1994, p. 160) describes the local velocity $U_{x}$ at a height $z$, where $z$ is less than half the height of the boundary layer at a distance $x$ from the leading edge of the substrate over which flow first passes:

$$
U_{x}=0.32 z U \sqrt{\frac{\rho U}{x \mu}}
$$

where $U$ is the freestream velocity and $\rho$ is the density of seawater $\left(1024 \mathrm{~kg} \mathrm{~m}^{-3}\right)$. For a freestream velocity of $10 \mathrm{~cm} \mathrm{~s}^{-1}$, typical though not maximal in the habitats where the species investigated here live (K. M. Sherrard unpubl. data), and a distance from the edge of $3 \mathrm{~cm}$, the local velocity reaches $50 \%$ of freestream velocity approximately $0.9 \mathrm{~mm}$ from the substrate. Because newly settled ascidians range in height from 0.1 to $1.5 \mathrm{~mm}$, many live well within such velocity boundary layers.

\section{RESULTS}

Three main considerations affect active suspension feeding in small juvenile ascidians. First, small size is associated with an unavoidably high resistance to flow, primarily due to the small diameter of the siphons. Second, perimeter of ciliated stigmata determines the available pump power. Finally, many early juveniles live deep within velocity boundary layers, where they are likely to experience lower quality food, and reduced nutrient and waste exchange. Juveniles could, therefore, improve their feeding capability by having relatively larger siphons, a relatively greater area of stigmata and by being relatively taller. Interestingly, no species exhibited the first 2 strategies and only 2 employed the third, while in several cases juvenile morphology ran counter to these considerations.

\section{Juvenile and adult morphologies were distinct}

Ciona juveniles were globose with a basal stalk and a short, wide incurrent siphon (Fig. 1A); in the course of ontogeny they became elongated, lost the stalk and developed relatively longer, narrower siphons (Fig. 1B). Both solitary stolidobranchs, Boltenia and 
Styela, were flat as early juveniles, with short and somewhat narrow siphons (Fig. 1C). Boltenia gradually became less flat and eventually globose, growing a stalk as an adult (Fig. 1D), whereas Styela became glo- bose earlier in ontogeny, developed relatively longer siphons and was elongate as an adult. Among colonial species, Distaplia oozooids changed from globose to elongate, gaining relatively wider siphons (Fig. 1E,F).
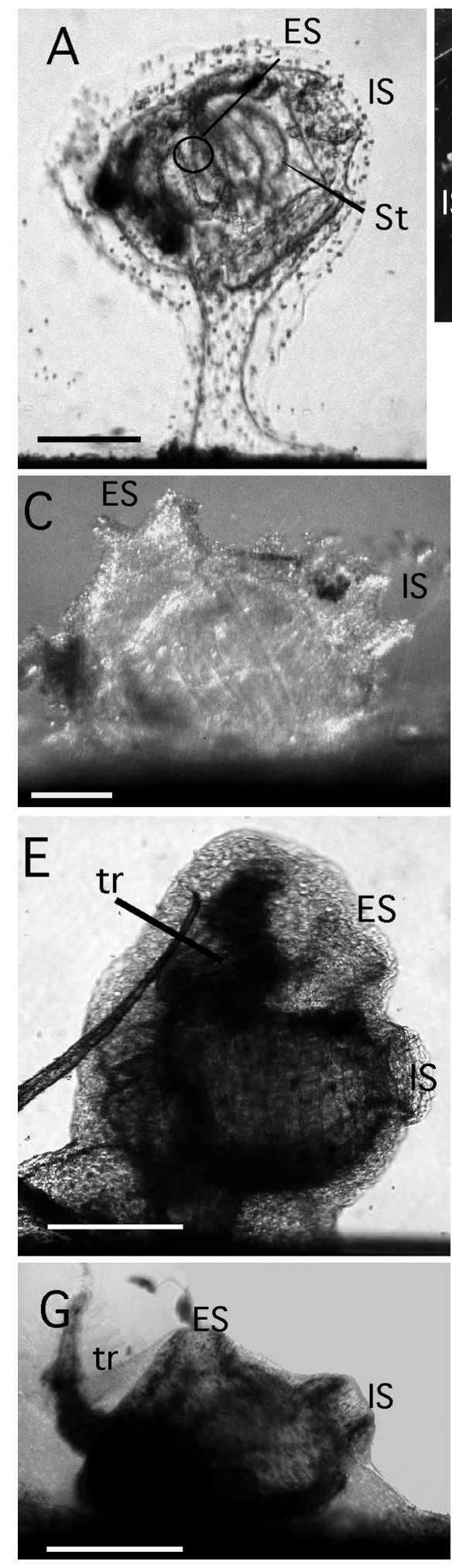
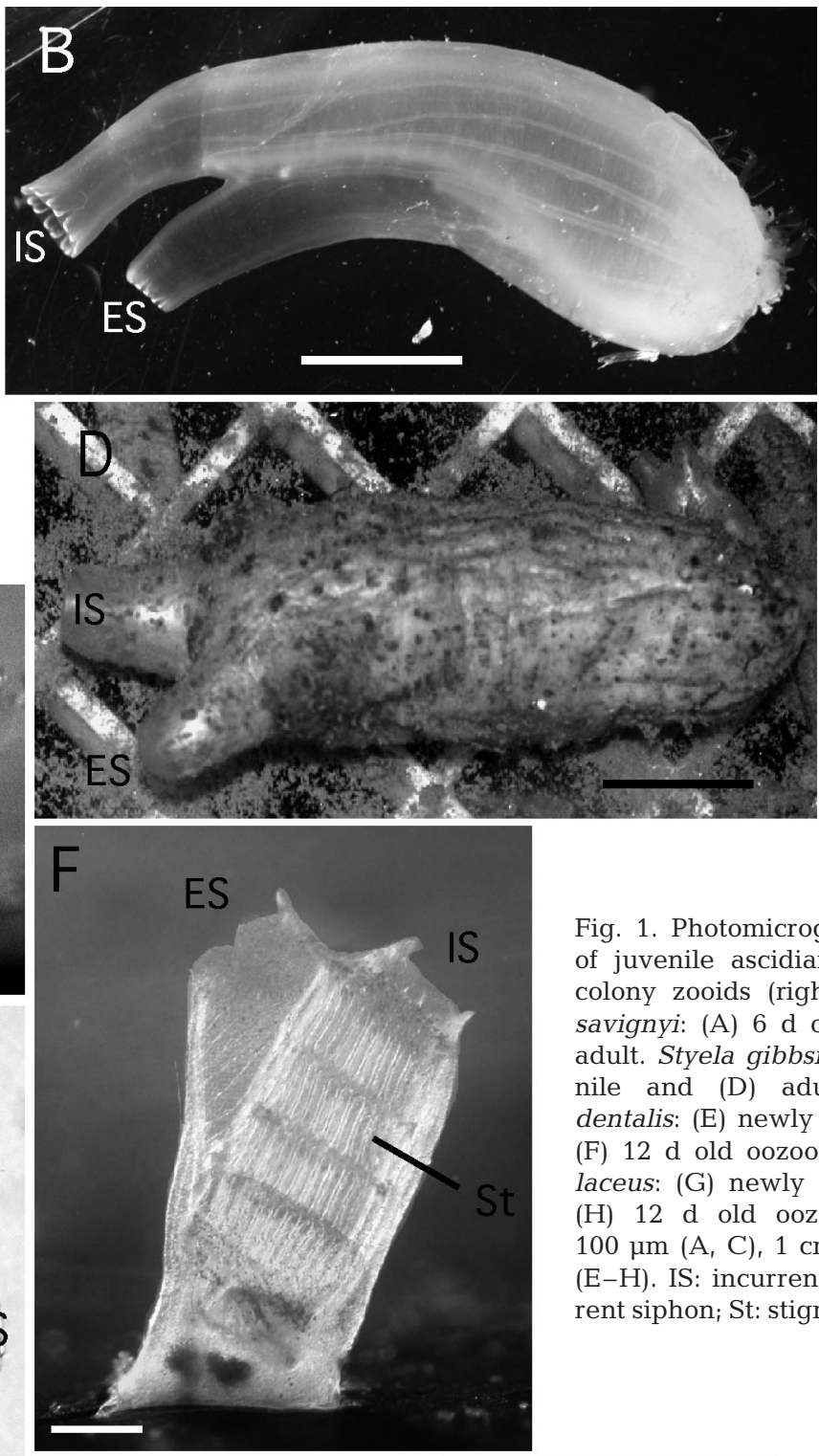

Fig. 1. Photomicrographs in side view of juvenile ascidians (left) and adult/ colony zooids (right) ascidians. Ciona savignyi: (A) 6 d old juvenile and (B) adult. Styela gibbsi: (C) 20 d old juvenile and (D) adult. Distaplia occidentalis: (E) newly settled oozooid and (F) 12 d old oozooid. Botrylloides violaceus: (G) newly settled oozooid and (H) $12 \mathrm{~d}$ old oozooid. Scale bars = $100 \mu \mathrm{m}(\mathrm{A}, \mathrm{C}), 1 \mathrm{~cm}(\mathrm{~B}, \mathrm{D})$ and $0.5 \mathrm{~cm}$ (E-H). IS: incurrent siphon; ES: excurrent siphon; St: stigmata; tr: tail remnant

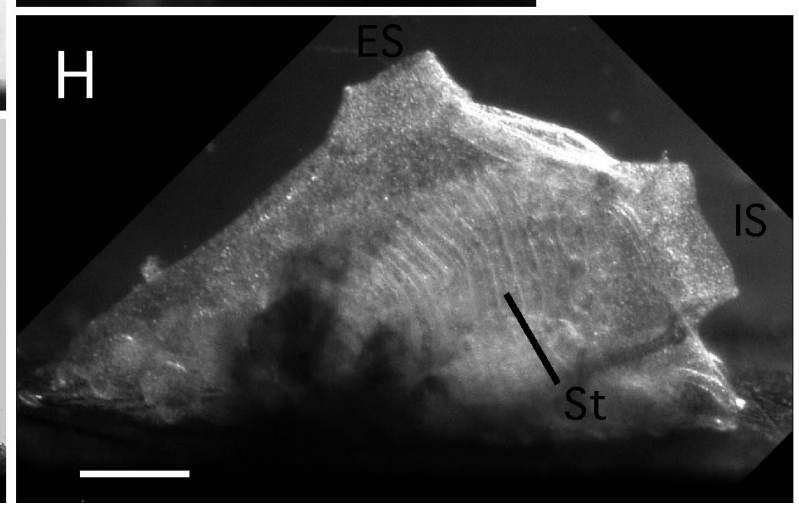


Table 1. Lateral body area $\left(\mathrm{mm}^{2}\right)$ regressed on dry mass $(\mathrm{mg})$ and ash-free dry mass (mg). Bootstrapped $95 \%$ confidence intervals in parentheses. Most species exhibited statistically indistinguishable isometric scaling (predicted isometric slope $=0.67$ ). Botrylloides early juveniles exhibited positive allometry, indicating that their early 'growth' is partly due to expansion of existing tissues. Pooled species values exclude Botrylloides. RMA: reduced major axis regression slope

\begin{tabular}{|c|c|c|c|c|c|c|}
\hline \multirow[t]{2}{*}{ Species } & \multicolumn{3}{|c|}{ Lateral area vs. dry mass } & \multicolumn{3}{|c|}{ Lateral area vs. ash-free mass } \\
\hline & RMA & $\mathrm{r}^{2}$ & $\mathrm{~N}$ & RMA & $r^{2}$ & $\mathrm{~N}$ \\
\hline Corella & $\begin{array}{c}0.68 \\
(0.64-0.73)\end{array}$ & 0.94 & 76 & $\begin{array}{c}0.66 \\
(0.61-0.73)\end{array}$ & 0.92 & 60 \\
\hline Ciona & $\begin{array}{c}0.7 \\
(0.59-0.92)\end{array}$ & 0.94 & 9 & $\begin{array}{c}0.7 \\
(0.52-0.90)\end{array}$ & 0.93 & 8 \\
\hline Distaplia & $\begin{array}{c}0.61 \\
(0.51-0.75)\end{array}$ & 0.85 & 16 & $\begin{array}{c}0.63 \\
(0.52-0.92)\end{array}$ & 0.82 & 14 \\
\hline Botrylloides & $\begin{array}{c}2.3 \\
(0.98-8.66)\end{array}$ & 0.27 & 10 & $\begin{array}{c}1.17 \\
(0.95-1.69)\end{array}$ & 0.8 & 10 \\
\hline Pooled & $\begin{array}{c}0.7 \\
(0.66-0.74)\end{array}$ & 0.67 & 101 & $\begin{array}{c}0.67 \\
(0.64-0.71)\end{array}$ & 0.92 & 82 \\
\hline
\end{tabular}

and therefore could not determine if they too have distinct scaling patterns at this early stage. The term 'young juveniles' refers to the stage immediately following early juveniles and 'later ontogeny' refers to the ontogeny encompassing young juveniles to adults.

Scaling of lateral body area with dry mass and ash-free dry mass was isometric and indistinguishable among species (Table 1), with the exception of the youngest Botrylloides, whose area initially increased with little gain in mass and for whom the scaling relationship was only marginally significant $(\mathrm{p}=0.0916$, regression coefficients). With this exception, the isometry of area with mass indicates that lateral area provides a biologically

Botrylloides oozooids changed little in overall shape as they grew, but siphons became relatively wider and longer (Fig. 1G,H).

Pairwise tests of the RMA regressions for the youngest Corella and Ciona juveniles (less than 3 wk post-settlement) against older individuals of the same species revealed that the scaling exponents of the youngest animals were significantly different from those of older juveniles and adults $(p \leq 0.0085$ in all cases; unless noted, p-values are from the permutations test, after Efron \& Tibshirani 1993). They were, therefore, treated as distinct groups in the scaling analysis based on lateral body area (less than $0.14 \mathrm{~mm}^{2}$ for Corella and less than $0.2 \mathrm{~mm}^{2}$ for Ciona); they are referred to as 'early juveniles', and this stage as 'early ontogeny'. We were not able to measure the morphologies of the earliest stages of Boltenia and Styela juveniles due to their flattened shape and opaque tunics, sound metric for scaling comparisons among different sizes and species.

Siphons were relatively narrower in early juveniles, but grew rapidly. The radius of the incurrent siphon (Table 2, Fig. 2A) was relatively smaller than in adults and increased with strongly positive allometry in early juveniles of the solitary species Corella and Ciona as well as in the much larger colonial oozooids of Distaplia and Botrylloides. With relatively narrower siphons initially, early juvenile stages have even higher siphonal resistance (Fig. 3) than their small size would suggest. In later ontogeny of solitary species, incurrent siphon radius increased with isometry or near isometry.

Young juveniles of Ciona appeared to have the largest incurrent siphon radius among solitary species, and Styela and Boltenia the smallest (see Fig. 2A), although elevations of the scaling relationships were not significantly different. Colonial oozooids had incur-

Table 2. Scaling of morphological variables. Note that the scaling of siphonal resistance is simply the scaling of the incurrent siphon radius multiplied by -3 . Isometry: isometric expectation under an assumption of geometric similarity; linear size: square

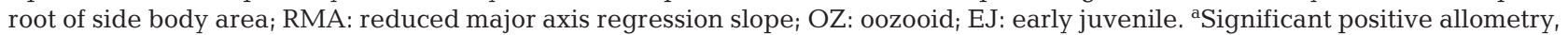
${ }^{\mathrm{b}}$ significant negative allometry, based on $95 \%$ confidence limits. ns: p-values for the correlation coefficients $>0.05$; thus slopes not significantly different from 0

\begin{tabular}{|c|c|c|c|c|c|c|c|c|c|c|c|c|c|c|c|}
\hline \multirow{2}{*}{$\begin{array}{l}\text { Species } \\
\text { Isometry }\end{array}$} & \multicolumn{3}{|c|}{$\begin{array}{l}\text { Incurrent radius } \\
\text { vs. linear size }\end{array}$} & \multicolumn{3}{|c|}{$\begin{array}{l}\text { Excurrent radius } \\
\text { vs. linear size }\end{array}$} & \multicolumn{3}{|c|}{$\begin{array}{l}\text { Incurrent length } \\
\text { vs. linear size }\end{array}$} & \multicolumn{3}{|c|}{$\begin{array}{l}\text { Stigmatal perimeter } \\
\text { vs. linear size }\end{array}$} & \multicolumn{3}{|c|}{$\begin{array}{l}\text { Height } \\
\text { vs. linear size }\end{array}$} \\
\hline & $\begin{array}{c}\text { RMA } \\
\quad 1\end{array}$ & $\mathrm{r}^{2}$ & $\mathrm{~N}$ & $\begin{array}{c}\text { RMA } \\
1\end{array}$ & $\mathrm{r}^{2}$ & $\mathrm{~N}$ & $\begin{array}{c}\mathrm{RMA} \\
1\end{array}$ & $\mathrm{r}^{2}$ & $\mathrm{~N}$ & $\begin{array}{c}\text { RMA } \\
2\end{array}$ & $r^{2}$ & $\mathrm{~N}$ & $\begin{array}{c}\text { RMA } \\
1\end{array}$ & $\mathrm{r}^{2}$ & $\mathrm{~N}$ \\
\hline Botrylloides OZ & $2.0^{\mathrm{a}}$ & 0.66 & 38 & $2.1^{\mathrm{a}}$ & 0.43 & 37 & $1.8^{\mathrm{a}}$ & 0.07 & 33 & 2.1 & 0.46 & 12 & 1.1 & 0.27 & 36 \\
\hline Distaplia OZ & $1.9^{\mathrm{a}}$ & 0.75 & 24 & $1.9^{\mathrm{a}}$ & 0.57 & 28 & $1.3^{\mathrm{a}}$ & 0.52 & 28 & 1.6 & 0.73 & 22 & $1.6^{\mathrm{a}}$ & 0.55 & 29 \\
\hline Ciona EJ & $2.2^{\mathrm{a}}$ & 0.7 & 13 & ns & 0.24 & 5 & 1.1 & 0.46 & 13 & 2.8 & 0.69 & 12 & ns & 0.12 & 14 \\
\hline Corella EJ & $2.3^{\mathrm{a}}$ & 0.68 & 10 & $\mathrm{~ns}$ & 0 & 12 & 1.4 & 0.21 & 17 & 1.7 & 0.73 & 17 & $1.8^{\mathrm{a}}$ & 0.32 & 17 \\
\hline Ciona & $0.88^{b}$ & 0.99 & 35 & $0.91^{\mathrm{b}}$ & 0.98 & 25 & $1.4^{\mathrm{a}}$ & 0.99 & 34 & $2.4^{\mathrm{a}}$ & 0.97 & 22 & $1.2^{\mathrm{a}}$ & 0.96 & 32 \\
\hline Corella & $1.1^{\mathrm{a}}$ & 0.96 & 41 & 0.92 & 0.96 & 18 & 1 & 0.93 & 24 & $2.3^{\mathrm{a}}$ & 0.98 & 68 & 1 & 0.97 & 62 \\
\hline Boltenia & 1 & 0.98 & 32 & 0.98 & 0.97 & 29 & 0.98 & 0.98 & 32 & $3.4^{\mathrm{a}}$ & 0.82 & 14 & $1.3^{\mathrm{a}}$ & 0.99 & 34 \\
\hline Styela & 0.97 & 0.96 & 48 & 0.97 & 0.93 & 42 & $1.1^{\mathrm{a}}$ & 0.94 & 48 & 2.5 & 0.7 & 15 & $1.3^{\mathrm{a}}$ & 0.98 & 50 \\
\hline
\end{tabular}



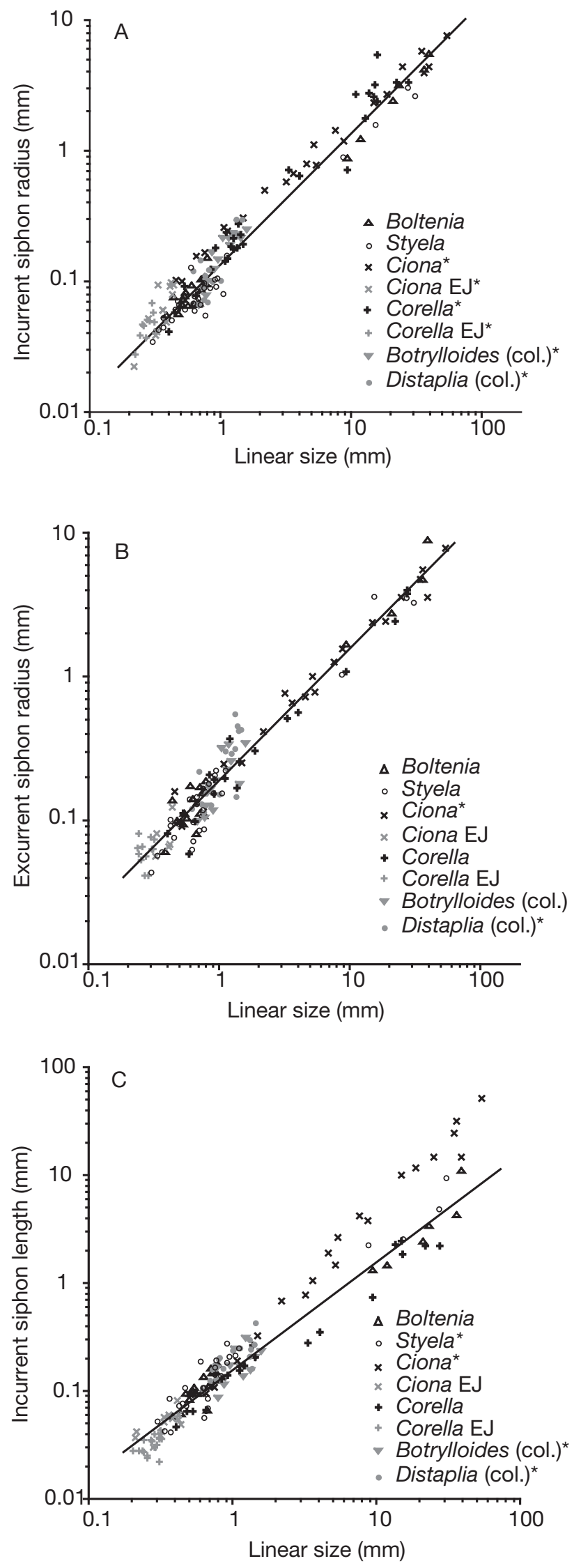

Fig. 2. Ontogenetic scaling of siphon measurements (mm) with linear size (square root of lateral body area). EJ: early juvenile; col.: colonial species. An isometric regression line is drawn for reference at elevation occupied by adults. Significant allometries (from reduced major axis slopes) are marked with an asterisk in the key. A representative subset of data is shown for greater legibility. See Table 1 for slopes and $r^{2}$ values. Both early juveniles and oozooids displayed strongly positive allometry in radii of (A) the incurrent siphon and (B) the excurrent siphon, in contrast to the isometry of larger individuals. Ciona juveniles had somewhat larger incurrent siphon radii relative to those of other species. (C) Length of incurrent siphon. Of the solitary species, only Ciona exhibited strongly positive allometry

rent siphon radii in the same size range as those of solitary species. However, Distaplia oozooids had relatively larger incurrent siphon radii than did Botrylloides ( $\mathrm{p}<0.0001$ for $\mathrm{y}$-intercepts).

The absolute size of the incurrent siphon in early juveniles presented an interesting contrast between solitary and colonial ascidians. Due to larger settlement size, colonial species had much lower resistance to flow than did solitary species. Siphonal resistance is proportional to the inverse cube of siphonal radius (Eq. 1), meaning that for a given shape of animal, it sharply increases as size decreases below a certain point. Fig. 4 shows siphonal resistance as a function of size for the species studied here. Whereas the colonial zooids avoided the region of sharp increases in resistance for small decreases in size, the solitary species did not, indicating that a substantial portion of early ontogeny was spent in a costly region of siphon morphospace.

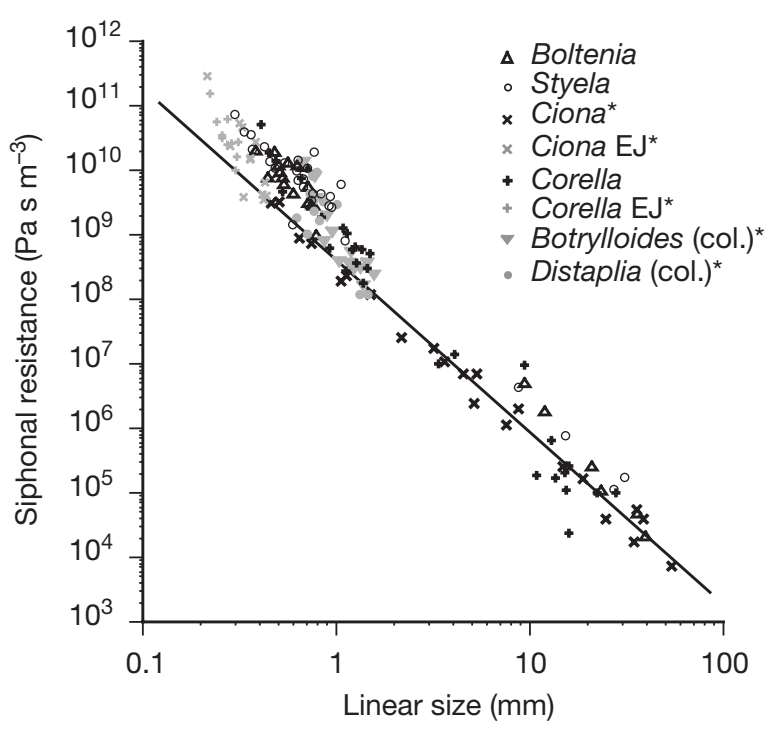

Fig. 3. Ontogenetic scaling of siphonal resistance $\left(\mathrm{Pa} \cdot \mathrm{s} \mathrm{m}^{-3}\right)$ with linear size. Early juveniles all had greater siphonal resistance than their body size would predict, corresponding to their relatively narrower siphons. Conventions as in Fig. 2 


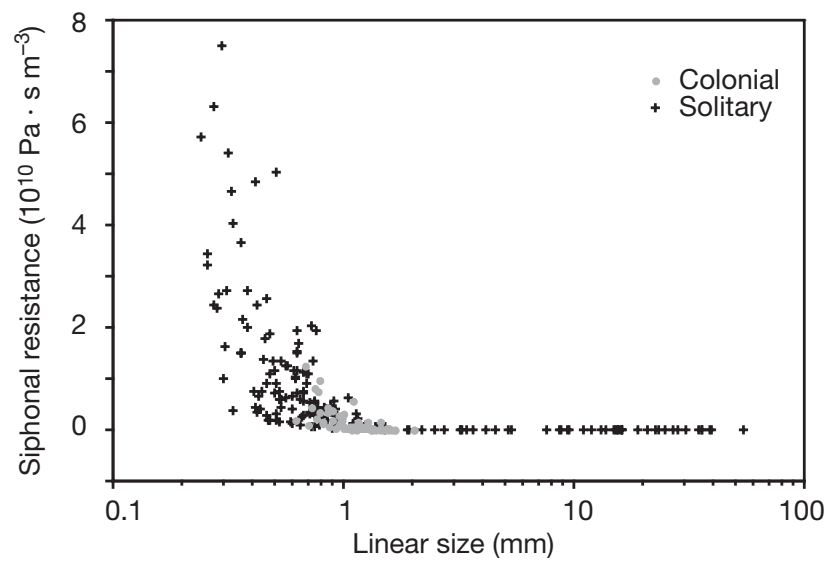

Fig. 4. Incurrent siphonal resistance $\left(10^{10} \mathrm{~Pa} \cdot \mathrm{s} \mathrm{m}^{-3}\right)$ to flow as a function of size. Solitary species (+) spend weeks in the steep part of the curve, where resistance is high. In contrast, juveniles of colonial species $\left({ }^{\circ}\right)$ are large enough that they fall mostly on the flat part of the curve. This suggests that selection has made colonial oozooids and blastozooids as small as possible without incurring disproportionately high siphonal resistance

The excurrent siphon radius scaled with similar trends to that of the incurrent, with positive allometry in early juveniles and isometry or slight negative allometry in solitary adults (Table 2, Fig. 2B). However, in early juveniles, the correlation coefficients were lower and apparent allometries were not significant. Further, in Corella and Ciona early juveniles, the $\mathrm{p}$-values for the correlation coefficients were not significant, indicating a lack of relationship between size and excurrent radius. In these species' juveniles, there was no significant relationship whether the radius of a single excurrent siphon or the total crosssectional area of both excurrent siphons was used; we report the results based on the former measure. Unlike incurrent siphon radius, excurrent siphon radius did not differ noticeably among species and values for juveniles were elevated relative to those for adults.

\section{Juvenile incurrent siphons were short}

Siphon length (Table 2, Fig. 2C) increased with positive allometry throughout the ontogeny of Ciona and Styela, whose adults have long siphons. It increased isometrically in the other 2 solitary species and with positive allometry in oozooids of colonial species. Colonial zooids had the same incurrent siphon lengths as did juveniles of solitary species in their size range. For narrow siphons, short length is especially critical to minimize resistance due to pressure drop along the length of the siphon.

\section{Stigmatal perimeter, a proxy for flow generation, increased proportionately with size}

Stigmatal perimeter (Table 2, Fig. 5) was slightly elevated in Corella early juveniles and in Distaplia oozooids, and there was a non-significant trend towards negative allometry, which suggests that early pumping rates are boosted in these species. The colonial oozooids, and Boltenia and Styela young juveniles had slightly greater stigmatal perimeters for their size than Corella and Ciona young juveniles, and Boltenia juveniles exhibited positive allometry for stigmatal perimeter (adults were not measured), as did Corella and Ciona subadults and adults. The fact that stigmatal perimeter was not relatively greater in early juveniles means that they do not have increased pumping power in the face of intrinsically higher resistance to flow.

\section{Height above substrate increased rapidly in juveniles}

Height (Table 2, Fig. 6) increased with strongly positive allometry in early juveniles of Corella and Ciona, and in oozooids of Distaplia, though correlation coefficients were low. Botrylloides oozooids increased isometrically in height. Height increased with positive allometry in the later ontogeny of Ciona, Boltenia and

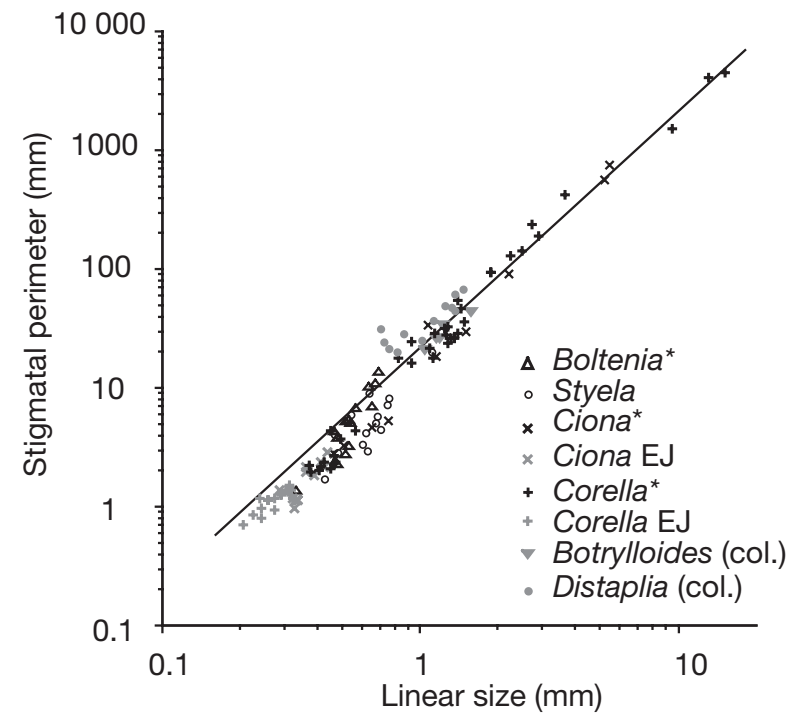

Fig. 5. Ontogenetic scaling of stigmatal perimeter $(\mathrm{mm})$ with linear size. Early and later juveniles had depressed RMA slopes relative to subadults and adults. The colonial oozooids of Botrylloides had similar values to those of most solitary juveniles; however, Distaplia oozooids, as well as Corella early juveniles, had elevated values of stigmatal perimeter. Only Boltenia had a regression slope that departed greatly from isometry. Conventions as in Fig. 2 


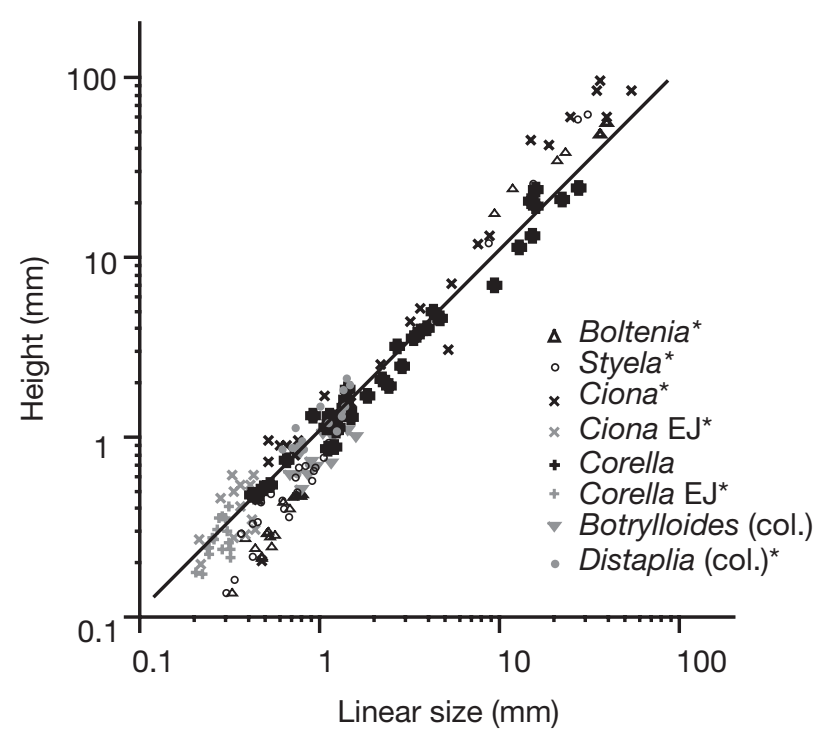

Fig. 6. Ontogenetic scaling of height (mm) with linear size. Of the solitary species, only Corella displayed isometric scaling of height, the others exhibiting positive allometry. Whereas small juveniles of Styela and Boltenia were shorter than those of Corella, Ciona juveniles were generally taller, due to their stalk. Early juveniles and Distaplia, though not Botrylloides oozooids, also displayed strongly positive allometry in height, and oozooids were no taller than solitary juveniles of equivalent size. Conventions as in Fig. 2; isometric line based on values for Corella

Styela, but isometrically in the later ontogeny of Corella. Ciona juveniles were the tallest among the solitary species, whereas Boltenia juveniles were the shortest (Fig. 1). Among adults, Ciona, Styela and Boltenia were of similar height, with Corella shorter. Botrylloides oozooids were similar in height to juveniles of solitary species in their size range, but Distaplia oozooids were somewhat taller. For an animal less than $1 \mathrm{~mm}$ tall, growing upwards quickly is likely to increase food intake.

\section{DISCUSSION}

Newly metamorphosed ascidians commence a benthic adult lifestyle at a microscopic length of as little as $200 \mu \mathrm{m}$. They are, nevertheless, capable of actively pumping fluid through their miniscule siphons and baskets with enough efficiency to grow, despite the inherent disadvantages of feeding from deep within velocity boundary layers. Although early juvenile ascidians possess the adult structures of siphons, stigmata and basket, their shapes and proportions differ. These differences in some cases improve feeding performance at small size and, in other cases, are the result of developmental or geometric limitations.
For example, regardless of adult morphology or settlement size, juveniles tended to have relatively shorter and narrower siphons. Short siphons reduce resistance to flow, but narrow siphons increase it. Short siphons are found in juveniles even of species (such as Ciona and Styela) that have long siphons as adults. Long siphons may benefit adult ascidians by allowing fluid to be collected further away from the substrate, where there is likely to be higher quality food available (Kott 1989). However, such benefits appear to be outweighed in young juveniles by resistance considerations.

The siphons of newly settled ascidians are narrow and enclosed within the stiff tunic as metamorphosis to the feeding juvenile begins (Davidson et al. 2003). Thus, it takes several days for siphons to expand to adult proportions and feeding commences while siphons are still relatively narrow. The initially narrow siphons of both solitary and colonial species appear to reflect a developmental constraint. Despite the initially high resistance to flow, it is nevertheless probably beneficial for early juveniles to begin feeding as early as possible, to exchange wastes (diffusion of ions is not efficient over as little as $100 \mu \mathrm{m}$, Howard 2001) and because the energy gained from feeding probably exceeds the cost of driving flow even at this higher resistance. Interestingly, most young juveniles did not reduce resistance further by continuing their positively allometric siphon growth after adult proportions were attained. Only Ciona had relatively wider siphons in juvenile than adult stages.

Ascidians have oral tentacles within the base of their incurrent siphons. In the species studied here, oral tentacles are narrow and mostly short (less than a tenth of siphon diameter), with about 4 close to 1 siphon radius in length in Corella and Distaplia. Because they are far from the axis of the siphon and obstruct little flow, oral tentacles do not increase the resistance appreciably, particularly at low Reynolds number where they cannot generate turbulent eddies (see Vogel 1994, p. 296).

Siphonal resistance challenges other small, internally pumping animals. Early juvenile brachiopods (Terebratalia transvera) gape their shells to a wider angle than do adults (M. LaBarbera unpubl. data). Furthermore, Declerck (1995) suggested that suspension feeding at small size was not cost-effective for juvenile gastropods due to higher resistance to flow.

It is, nevertheless, possible that narrow siphons confer some advantages to juveniles. By increasing the incurrent velocity for a given volumetric flow rate, they make it possible to capture motile particles from a greater distance. Additionally, animals with narrow siphons operate at a sufficiently low Reynolds number (ca. 0.1) that they are capable of sensing particles before entry and rejecting them if they are too large 
(Sherrard 2003, Sherrard \& LaBarbera 2005 this issue), a feat impossible in larger subadults. Adult ascidians have no mechanism for sorting individual particles. To expel particles, adults must interrupt their feeding to violently contract the branchial basket (Armsworthy et al. 2001). Our observations suggest that the oral tentacles of both adults and juveniles screen out primarily long, narrow particles, and not always very effectively. Preventing the entry of unwanted particles such as parasites or those too large to swallow may be a particularly important consideration for early juveniles.

The paired excurrent siphons of Corella and Ciona, typical of early juveniles of the suborder Phlebobranchiata (Berrill 1950, Kott 1969), are a puzzling feature with regard to hydrodynamics. The initially lateral siphons merge dorsally at approximately 1 mo postsettlement. The paired siphons sum to an area proportional to that of a single excurrent siphon in older animals, relative to incurrent siphon area and body size (data not shown), thus increasing the siphonal wall area by ca. $40 \%$ and generating a higher resistance to flow. This would tend to decrease suspension feeding efficiency. However, the excurrent openings are positioned directly over the stigmata (see Fig. 1A); thus, they may incur less resistance than would a medial siphon that required excurrent flow to be transported much further within the atrium.

Scaling of stigmatal perimeter suggests that juveniles generate, at best, equivalent and often reduced pump power relative to adults, while facing greater resistance to flow. It is likely that geometric constraints limit stigmatal perimeter in the smallest juveniles to a greater degree than in adults. The stigmata are long, with a nearly invariant width determined by ciliary length and by constraints on efficient flow (Grunbaum et al. 1998). The absence of circular stigmata suggests that shape is not efficient for flow generation. While the 2 pairs of protostigmata (see Fig. 1A) borne by newly metamorphosed solitary juveniles may be of optimal size relative to the basket, early addition of stigmata is likely to be limited by basket size. Thus, the relatively dense stigmatal perimeters of the youngest solitary juveniles may not be attainable by later juveniles until basket size becomes large enough to permit efficient addition of stigmata. Although Boltenia exhibited positive allometry of stigmatal perimeter (and Styela displayed a trend towards it), their values were depressed relative to the other species (see Fig. 5) and the data are compromised by covering only a small portion of ontogeny. Finally, the positive allometry of stigmatal perimeter exhibited by later ontogenetic stages of Corella and Ciona suggests that they may generate relatively higher flow rates as they get larger.

Height above the substrate generally increased with positive allometry, indicating that growing upwards is an important consideration throughout ontogeny. Raising oneself quickly beyond velocity boundary layers is likely to strongly affect nutrient availability for small organisms. Interestingly, height was highly variable among juveniles, often without regard to the form of conspecific adults. The flattened forms of juvenile Boltenia and Styela, distinct from stalked and elongated adults, place juveniles even deeper within boundary layers than they would otherwise be. However, it is not known to what extent height above substrate directly affects juvenile performance by increasing mortality risk and decreasing food intake.

The lack of a significant regression between size and excurrent siphon radius in Corella and Ciona early juveniles, and size and height in Ciona early juveniles is likely due to the small size range covered by the data, which makes it more difficult to extract patterns from noise inherent in the measurements. It is all the more striking that the other morphological parameters did generate highly significant relationships.

\section{Suspension feeding in juveniles of colonial species}

The morphological data suggest that colonial zooids are, at best, only slightly more specialized for suspension feeding at small size than juveniles of solitary species. Distaplia zooids were slightly taller and had slightly greater stigmatal perimeters than same-sized solitary juveniles, suggesting that Distaplia may be capable of greater food intake. However, Botrylloides' height and stigmatal perimeters were no different from those of solitary juveniles, and both species had similar siphon radii and length compared with same-sized solitary juveniles. One telling functional advantage of settling at larger size is that colonial zooids are just large enough to avoid heavy costs in siphon resistance (see Fig. 4). This suggests that selection for avoiding prohibitively high resistance to flow has acted more strongly in colonial than in solitary ascidian juveniles.

\section{Juvenile morphologies fit life-history strategies}

Species-specific differences in early juvenile morphologies reflect divergent responses to a tradeoff between early juvenile growth rates and survival. In Ciona and Corella, early juvenile morphological features favoring feeding performance coincide with lifehistory traits of rapid growth, short generation time and high mortality rates. Ciona's stalk nearly doubled its height and its larger siphons reduced resistance to flow and Corella early juveniles also had an upright morphology. The positive allometry of stigmatal perimeter in Ciona suggests that size-specific volumet- 
ric flow rate may increase with size, provided siphonal resistance does not increase too much as the siphons lengthen. Additionally, both Ciona and Corella had thin and flimsy tunics relative to those of the other species, which may entail less energetic investment and may also permit faster expansion during growth.

In contrast, Styela and Boltenia had more flattened forms and relatively narrower siphons as early juveniles, traits expected to reduce feeding efficiency. Their tunic material is substantially stiffer and stronger than that of Corella (Young 1985, 1986), which could hinder rapid expansion of the juvenile body. They have much slower early juvenile growth rates compared with Ciona and Corella, but higher survival in the field (Sherrard 2003, M. W. Jacobs \& K. M. Sherrard unpubl. data). Further, laboratory and field studies have shown that stolidobranch ascidians such as Boltenia and Styela survive predation and mechanical insult better than do phlebobranchs such as Corella and Ciona (Svane 1983, Young \& Chia 1984, Young 1985, 1986). Thus, in Boltenia and Styela morphological features less favorable to early juvenile feeding performance co-occur with life-history traits of slow growth, longevity and lower mortality rates.

Among colonial species, Distaplia had a longer body, wider siphons, greater stigmatal perimeter and a flimsier tunic than Botrylloides, features that are expected to favor a higher food intake, growth rate and mortality rate. Laboratory and field studies found higher mortality rates in Distaplia than Botrylloides, but lower growth rates as well (Sherrard 2003, M. W. Jacobs \& K. M. Sherrard unpubl. data). Clearly, morphological differences are only one piece of the puzzle. Diverse factors, including digestive efficiency, amount of food reserves in the newly settled juvenile (dry mass data in Table 1 suggest that Botrylloides bolsters early growth with nutrient reserves) and settlement locale (affecting food availability via current flux and competition, as well as predation risk), also strongly influence growth and mortality rates.

\section{Phylogenetic context}

A number of recent cladistic phylogenies have supported monophyly of the 3 traditional ascidian suborders (Aplousobranchiata, Phlebobranchiata and Stolidobranchiata) (Wada 1998, Swalla et al. 2000, Stach \& Turbeville 2002). Additionally, a number of researchers (e.g. Berrill 1950, Kott 1969) have considered the aplousobranchs and phlebobranchs to be more closely related to each other than either is to stolidobranchs. In this light, it is interesting to consider the divergence in life-history strategies among the species studied here. The solitary phlebobranchs Corella and Ciona together with the colonial aplousobranch Distaplia appear to be specialized for rapid early growth at the cost of higher mortality, while the colonial and solitary stolidobranchs Botrylloides, Boltenia and Styela employ the opposite strategy. Investigating more species in each group would determine how generally this pattern holds.

\section{CONCLUSIONS}

Newly feeding juveniles of both solitary and colonial ascidians are saddled with a number of sub-optimal morphologies, such as disproportionately narrow siphons, limited stigmatal perimeter and short stature. These constitute developmental constraints, which are an unavoidable consequence of commencing feeding several days to a week before adult proportions are attained.

A second type of constraint on feeding performance arises because of an inherent conflict between morphologies that favor survival and those that favor rapid growth rates. Morphologies likely to improve early juvenile suspension feeding performance, such as being taller and having wider siphons, are likely to make juveniles more vulnerable to predation and other forms of mechanical damage. The marked differences in early juvenile morphologies suggest that the various species have evolved several distinct strategies relating to the tradeoff between early juvenile growth and survival rates.

Acknowledgements. We thank D. Grunbaum, C. Pfister, J. Voight, J. Socha, members of the Friday Harbor Laboratories journal club (M. Jacobs, T. McGovern, R. Wyeth, J. Schulz and S. Lindsey) and 3 anonymous reviewers for helpful comments on the manuscript. We are grateful to A. O. D. Willows and the staff of Friday Harbor Laboratories for making facilities available for this research. The work was part of K.S.'s doctoral dissertation and was funded by the University of Chicago Hinds fund, a Friday Harbor Labs Alan Kohn Fellowship, a Sigma Xi Grant-in-Aid-of-Research, a Society for Integrative and Comparative Biology Grant-in-Aid-of-Research, and an NSF Doctoral Dissertation Improvement Grant (\# 0206026).

\section{LITERATURE CITED}

Armsworthy SL, MacDonald BA, Ward JE (2001) Feeding activity, absorption efficiency and suspension feeding processes in the ascidian, Halocynthia pyriformis (Stolidobranchia: Ascidiacea): responses to variations in diet quantity and quality. J Exp Mar Biol Ecol 260:41-69

Arsenault DJ, Girard P, Himmelman JH (1997) Field evaluation of the effects of refuge use and current velocity on the growth of juvenile Iceland scallops, Chlamys islandica (O.F. Muller, 1776) J Exp Mar Biol Ecol 217:31-45

Berrill NJ (1950) The Tunicata (with an account of the British species). Adlard \& Son, London

Buss LW, Jackson JBC (1981) Planktonic food availability and 
suspension-feeder abundance: Evidence of in situ depletion. J Exp Mar Biol Ecol 49:151-161

Connell JH (1985) The consequences of variation in initial settlement vs post-settlement mortality in rocky intertidal communities. J Exp Mar Biol Ecol 93:11-45

Davidson B, Smith Wallace SE, Howsmon R, Swalla BJ (2003) A morphological and genetic characterization of metamorphosis in the ascidian Boltenia villosa. Dev Genes Evol 213:601-611

Declerck CH (1995) The evolution of suspension feeding in gastropods. Biol Rev Camb Philos Soc 70:549-569

Efron B, Tibshirani RJ (1986) Bootstrap methods for standard errors, confidence intervals, and other measures of statistical accuracy. Stat Sci 1:54-77

Efron B, Tibshirani RJ (1993) An introduction to the bootstrap. Chapman and Hall, New York

Fiala-Medioni A (1978) Filter-feeding ethology of benthic invertebrates (Ascidians). IV. Pumping rate, filtration rate, filtration efficiency. Mar Biol 48:243-249

Flood P, Fiala-Medioni A (1979) Filter characteristics of Ascidian food trapping mucous films. Acta Zool 60:271-272

Flood PR, Fiala-Medioni A (1981) Ultrastructure and histochemistry of the food-trapping mucous film in benthic filter-feeders (Ascidians). Acta Zool 62:53-65

Goodbody I (1963) The biology of Ascidia nigra (Savigni). II. The development and survival of young ascidians. Biol Bull (Woods Hole) 124:31-44

Gosselin LA, Qian PY (1997) Juvenile mortality in benthic marine invertebrates. Mar Ecol Prog Ser 146:265-282

Grunbaum D, Eyre D, Fogelson A (1998) Functional geometry of ciliated tentacular arrays in active suspension feeders. J Exp Biol 201:2575-2589

Howard J (2001) Mechanics of motor proteins and the cytoskeleton. Sinauer Associates, Sunderland, MA

Hunt HL, Scheibling RE (1997) Role of early post-settlement mortality in recruitment of benthic marine invertebrates. Mar Ecol Prog Ser 155:269-301

Jørgensen CB, Kiorboe T, Mohlenberg F, Riisgård HU (1984) Ciliary and mucous-net filter feeding, with special reference to fluid mechanical characteristics. Mar Ecol Prog Ser 15:283-292

Keesing JK, Halford AR (1992) Field measurement of survival rates of juvenile Acanthaster planci: techniques and preliminary results. Mar Ecol Prog Ser 85:107-114

Koehl MAR (1996) When does morphology matter? Annu Rev Ecol Syst 27:501-542

Kott P (1969) Antarctic Ascidia. Antarctic Research Series 13. National Academy of Sciences, Washington, DC

Kott P (1989) Form and function in the Ascidiacea. Bull Mar Sci 45(2):253-276

Kowalke J (1999) Filtration in Antarctic ascidians - striking a balance. J Exp Mar Biol Ecol 242:233-244

LaBarbera M (1984) Feeding currents and particle capture mechanisms in suspension feeding animals. Am Zool 24: $71-84$

LaBarbera M (1989) Analyzing body size as a factor in ecology and evolution. Annu Rev Ecol Syst 20:97-117

Martinucci GB, Dallai R, Burighel P (1987) A comparative study of ciliary differentiations in the branchial stigmata of ascidians. Tissue Cell 19(2):251-263

Moran AL (1999) Size and performance of juvenile marine invertebrates: potential contrasts between intertidal and subtidal benthic habitats. Am Zool 39(2):304-312

Moran AL, Emlet RB (2001) Offspring size and performance in variable environments. Ecology 82(6):1597-1612

Nowell ARM, Jumars PA (1984) Flow environments of aquatic benthos. Annu Rev Ecol Syst 15:303-328
Osman RW, Whitlatch RB (1995) Predation on early ontogenetic life stages and its effect on recruitment into a marine epifaunal community. Mar Ecol Prog Ser 117:111-126

Osman RW, Whitlatch RB (1996) Processes affecting newly-settled juveniles and the consequences to subsequent community development. Invertebr Reprod Dev 30:217-225

Osman RW, Whitlatch RB, Malatesta RJ (1992) Potential role of micro-predators in determining recruitment into a marine community. Mar Ecol Prog Ser 83:35-43

Petersen JK, Riisgård HU (1992) Filtration capacity of the ascidian Ciona intestinalis and its grazing impact in a shallow fjord. Mar Ecol Prog Ser 88:9-17

Petersen JK, Svane I (2002) Filtration rate in seven Scandinavian ascidians: implications of the morphology of the gill. Mar Biol 140:397-402

Plotnick RE (1989) Application of bootstrap methods to reduced major axis line fitting. Syst Zool 38:144-153

Randløv A, Riisgård HU (1979) Efficiency of particle retention and filtration rate in four species of Ascidians. Mar Ecol Prog Ser 1:55-59

Riisgård HU (1988) The ascidian pump: properties and energy cost. Mar Ecol Prog Ser 47:129-134

Riisgård HU, Larsen PS (1995) Filter-feeding in marine macro-invertebrates: Pump characteristics, modeling, and energy cost. Biol Rev Camb Philos Soc 70:67-106

Riisgård HU, Jørgensen C, Clausen T (1996) Filter-feeding ascidians (Ciona intestinalis) in a shallow cove: implications of hydrodynamics for grazing impact. J Sea Res 35(4):293-300

Rose MR, Lauder GV (1996) Adaptation. Academic Press, San Diego, CA

Rubinstein DI, Koehl MAR (1977) The mechanisms of filter feeding: Some theoretical considerations. Am Nat 111: 981-994

Sherrard KM (2003) A comparative study of early juvenile feeding performance in ascidians. PhD thesis, University of Chicago, Chicago

Sherrard KM, LaBarbera M (2005) Form and function in early juvenile ascidians. II. Ontogenetic scaling of volumetric flow rates. Mar Ecol Prog Ser 287:139-148

Stach T, Turbeville JM (2002) Phylogeny of Tunicata inferred from molecular and morphological characters. Mol Phylog Evol 25:408-428

Stoner DS (1990) Recruitment of a tropical colonial ascidian: relative importance of pre-settlement vs post-settlement processes. Ecology 7(5):1682-1690

Svane I (1983) Ascidian reproductive patterns related to longterm population. Sarsia 68(4):249-255

Swalla BJ, Cameron CB, Corley LS, Garey JR (2000) Urochordates are monophyletic within the deuterostomes. Syst Biol 49(1):52-64

Vogel S (1994) Life in moving fluids. Princeton University Press, Princeton, NJ

Wada H, Makabe KW, Nakauchi M, Satoh N (1992) Phylogenetic relationships between solitary and colonial ascidians, as inferred from the sequence of the central region of their respective 18S rDNAs. Biol Bull (Woods Hole) 183: 448-455

Young CM (1985) Abundance patterns of subtidal solitary ascidians in the San Juan Islands, Washington, as influenced by food preferences of the predatory snail Fusitriton oregonensis. Mar Biol 84:309-321

Young CM (1986) Defenses and refuges: alternative mechanisms of coexistence between a predatory gastropod and its ascidian prey. Mar Biol 91:513-522

Young CM, Chia FS (1984) Microhabitat-associated variability in survival and growth of subtidal solitary ascidians during the first $21 \mathrm{~d}$ after settlement. Mar Biol 81:61-68 